\title{
Post-acquisition Changes Beyond the Dyad: Power at the Net Level in Cross-Border Acquisitions ${ }^{(1)}$
}

\author{
Sérgio Fernando Loureiro Rezende* \\ E-mail address: srezende@pucminas.br \\ Pontifícia Universidade Católica de Minas Gerais - PUC-Minas, Mestrado Profissional em Administração \\ Belo Horizonte, MG, Brazil \\ Roberto Gonzalez Duarte \\ E-mail address: robertoduarte@pucminas.br \\ Pontifícia Universidade Católica de Minas Gerais - PUC-Minas, Mestrado Profissional em Administração \\ Belo Horizonte, MG, Brazil
}

\begin{abstract}
A common feature of the literature on post-acquisition changes is its dyadic feature, i.e. the emphasis is placed on the actors directly involved in the acquisition, often represented by the acquiree and the acquirer. Accordingly, actors outside the dyad, such as suppliers and buyers, are usually disregarded. There is, however, a relevant exception in this literature. Recently, some Nordic authors have claimed that if actors other than the acquiree and the acquirer are not taken into account, the existing literature may only present a partial view of changes following acquisitions. Consequently, they have suggested that changes following this type of operation can be analysed fruitfully at the network level. Our article adds to the efforts of these scholars to understand post-acquisition changes at a broader level by bringing to the fore two issues that have received scarce attention in the literature: i) nets rather than the network level appears to be the locus where post-acquisition changes beyond the dyad take place; ii) relational power can be regarded as an independent variable in post-acquisition changes beyond the dyad. These arguments are illustrated by three brief case studies of cross-border acquisitions.
\end{abstract}

Key words: network; post-acquisition changes; dyad; relational power.

Received 14 October 2003; received in revised form 26 February 2004.

Copyright (C) 2004 Brazilian Administration Review. All rights reserved, including rights for translation. Parts of this work may be quoted without prior knowledge on the condition that the source is identified.

* Corresponding author: Sérgio Fernando Loureiro Rezende

Rua Dom José Gaspar, 500, prédio 14, sala 113, Coração Eucarístico, Belo Horizonte, MG, 30535-610, Brazil. 


\section{INTRODUCTION}

Foreign Direct Investment (FDI) flows as well as mergers and acquisitions (M\&A) have recently increased significantly. In 1999 global inflows reached $\$ 865$ billion, an increase of 27 per cent over the previous year. As far as cross-border M\&As are concerned, they rose from $\$ 75$ billion in 1987 to $\$ 720$ billion in 1998 (UNCTAD, 2000). Against this backdrop, a number of scholars have been concerned with various issues regarding M\&As such as post-acquisition integration and management, and post-acquisition performance. Although the efforts of these scholars have produced a burgeoning literature, there appears to be a common feature to these scholarly works: the analysis is focused on the dyad, i.e. on the actors directly involved in the acquisition process, often represented by the acquiree and the acquirer. Accordingly, actors outside the dyad such as suppliers and buyers are usually disregarded.

There is, however, a relevant exception in the literature. Some Nordic authors such as Havila and Salmi, $(2000,2002)$ have appropriately claimed that the existing literature presents an incomplete picture of acquisitions because it does not consider actors other than the acquirer and the acquiree. Based on conceptual notions from the so-called 'market-as-networks' approach (e.g. HAKANSSON; SNEHOTA, 1995), they have suggested that changes following acquisitions should be analysed at the network level.

Our article adds to the efforts of these scholars to understand post-acquisition changes at a broader level, henceforth called 'post-acquisition changes beyond the dyad', by pointing out two key issues that have received scarce attention in the literature on networks. First, unlike the Nordic scholars, it is our contention that nets rather than the network appear to be the 'locus' where post-acquisition changes beyond the dyad take place. This means that an acquisition (for brevity we refer to acquisition as a cross-border acquisition) does not necessarily affect networks homogeneously. Changes are likely to vary in terms of type and strength of connected relationships embedded in different nets. Secondly, this article brings to the fore the issue of power balancing among different actors in the network (FORSGREN; OLSSON, 1992). Our claim is that post-acquisition changes beyond the dyad revolve around the distribution of power among the dyad, suppliers, and buyers.

This article is structured as follows: in the first section, we briefly review the literature on acquisition. In the second section, we introduce the works of the Nordic scholars who have claimed that post-acquisition changes could more fruitfully be analysed at a broader level. In the third section, we discuss the power issue in networks and suggest that post-acquisition changes beyond the dyad can be explained through the lens of power. In the fourth section, we present three brief case studies of Brazilian firms that were acquired by European or American firms. In the fifth section, we discuss the major results of the case studies and finally, we offer some conclusions and we outline implications for future research.

\section{The Dyadic Feature Of The Literature On ACQUisition}

Broadly, the literature on acquisition concentrates on three different stages: ex-ante the acquisition, during the acquisition and ex-post the acquisition. Each stage has to do with value creation, i.e. how an acquisition creates value. Regardless of the factors - organisational, strategic, or contextual - chosen to shed light on the value-creation issue, there appears to be a common axis to this literature: the emphasis is placed on the dyad, i.e. the acquiree-acquirer and their mutual relationship.

The ex-ante stage is related to the potential value creation that might follow an acquisition. More specifically, the decision-making leading to an acquisition is based on the assumption that the acquirer will contribute to either the strategic or the financial improvement of the acquiree (SCHWEIGER et al., 1994; VON KROGH et al., 1994). On the one hand, research suggests that related firms are more 
likely to create value (HUNT, 1990; LINDGREN, 1982; LORANGE, 1994; LUBATKIN et al., 1998). On the other hand, it has been argued that value creation does not rely only on relatedness, but also depends on organisational factors (DAVID; SINGH, 1994; DUBINI, 1994; HASPESLAGH; JEMISON, 1991). Value creation may, for instance, be subject to compatibility of management styles (DAVIS, 1968; DATTA, 1991) or to congruence of culture, leadership, and structure between acquiree and acquirer (NAHAVANDI; MALEKZADH, 1994).

The second stage, during the acquisition, has to do with real value creation which is, in turn, associated with integration and management of the acquiree. It has been suggested that the degree of integration of the acquiree into the acquirer, i.e. the autonomy assigned to the acquiree, varies according to strategic and organisational task needs (PABLO, 1994), relatedness (LINDGREN; SPANGBERG, 1981), and nationality of the acquirer (CHILD et al., 2001). In a similar vein, it has been said that the management of the acquiree is liable to either strategic or organisational factors such as the timing of changes and the pace of integration (BIRKINSHAW et al., 2000) and cultural clashes (KANTER; CORN, 1994).

Finally, at the ex-post stage, studies on post-acquisition performance attempt to understand how value is created from acquisitions. Because a high rate of acquisition failure has been observed (KRUGER; MULLER-STEWENS, 1994; NAHAVANDI; MALEKZADEH, 1994), authors have sought to identify which reasons are more likely to determine the success (or value creation) of an acquisition. Strategic factors (KITCHING, 1974), managerial factors (CHILD et al., 1999), or a composite of contextual and managerial factors (DATTA; GRANT, 1990; HITT et al., 1998) have been proposed.

This brief review of the literature on acquisition reveals that the emphasis has been given to the units directly involved in the acquisition, i.e. the acquiree and the acquirer. Because the dyadic relationship was chosen as the unit of analysis, factors outside it that eventually affect value creation, postacquisition integration, management and performance have generally been overlooked.

\section{MulTiPle LeVels of Change IN ACQUisitions}

By following a different theoretical standpoint, Halinen et al. (1999) suggest that changes following acquisitions are not necessarily confined to the dyad. Actors linked directly and/or indirectly to the dyad may be affected by changes initiated within and/or requested by the dyad. They may also make countervailing moves, thus affecting the dyad (GASKI, 1984; FORSGREN; OLSSON, 1992). In this sense, changes in acquisitions appear to be circular rather than unidirectional (HALINEN et al., 1999). If this proposition holds, a multi-layered analysis of post-acquisition changes is required. This involves the firm, the dyad, the net and the network as a whole (HERTZ, 1998).

Our interest in this section is on the net and the network levels, although these levels are less clearly defined. In the 'market-as-networks' approach it appears that the usage of these two terms is "by no means consistent" (EASTON, 1992, p. 18). The difference between net and network appears to be, above all, "a question of level of aggregation" (ibid., 18) and, as a result, net can be defined as a subdivision of the network. Smith and Laage-Hellman (1992) also contend that delimiting net or network boundaries is non-trivial and propose strategies to tackle this issue. The one adopted here is to take into account actors with specific identities such as suppliers and buyers. This means that a network will be conceptualised here as consisting of a number of buyer and supplier nets.

The theoretical move from dyads to a broader level in order to analyse post-acquisition changes has received an important contribution from some Nordic scholars. Anderson et al. (2001), for example, propose to classify changes following acquisitions into 'planned' and 'unplanned'. Planned changes are those expected by the dyad whereas unplanned changes are not predicted beforehand. In the latter case, either the acquirer or the acquiree is unable to accurately predict the effects of the acquisition on the actors to whom they are directly or indirectly connected. 
Changes following acquisitions can also be classified into 'evolutionary' or 'revolutionary'. The evolutionary changes imply the maintenance of actor bonds, activity links, and resource ties within the relationships involved in the process of acquisition, whereas revolutionary changes mean terminating relationships and consequently breaking bonds, links and ties (Easton, 1992). When a revolutionary change occurs usually a new network of relationships appears, i.e. the structure of the network in which the dyad is embedded is altered. Havila and Salmi $(2000,2002)$ classify changes following acquisitions as revolutionary when old relationships are disrupted and new relationships are built.

Halinen et al. (1999) distinguish between 'confined' and 'connected' changes. Confined changes refer to changes following acquisitions that remain within the dyad while connected changes are those that affect direct and indirect relationships linked to the dyad. In this context, it is proposed that the role of the dyad is threefold. It generates, receives, and transmits changes.

Whilst acknowledging that post-acquisition changes are liable to patterns of interactions among different actors in a network, this body of research has opened up new avenues for empirical investigation. An unexplored yet fruitful one is to examine how power relations can be used to explain post-acquisition changes beyond the dyad. According to Hakansson and Ford (2002, p. 135), "a change in a network always involves changes in both companies and relationships. This means that a company seeking change is always dependent on the approval and actions of others to achieve the change". Put another way, changes in networks, in particular those triggered by acquisitions, can theoretically be related to the balance or exercise of power among these actors. Or, as Forsgren and Olsson (1992, p. 192) put it, "the tendency to preserve the balance of power between actors can be used to explain changes in industrial networks". The theoretical combination of power and postacquisition changes beyond the dyad is developed in the next section.

\section{POWER ANd POST-ACQUISITION ChANGes BeyOND the Dyad}

An assumption of this article is that power can be conceptualised in relational terms (GALASKIEWICZ, 1985). Accordingly, power exists because actors are dependent upon each other for resources in exchange relations (COOK, 1977). Here, two qualifications are important. First, resources can be regarded as anything which firms need for carrying out activities (ZEITZ, 1980). Resources are tangible items such as machines and semi-finished products as well as symbolic items such as legitimacy (FARIA; WENSLEY, 2002). Secondly, not all resources entail dependence relations between actors in exchange relations. Resources perceived to be essential by a particular actor and/or resources that are not easily obtained from alternative sources are those in which dependence relations are rooted. These two aspects are what Jacobs (1974) refers to as 'essentiality' and 'availability' of resources.

However, power does not derive only from resource dependence in exchange relations. Cook (1977), for instance, proposes that power also has a structural component. This means that the location or position in the network can be a source of power to a particular actor to the extent that 'centrality makes an organization crucial to the resource acquisition of other agencies' (BENSON, 1975, p. 233).

Power in relational terms need not be exercised in order to exist (EMERSON, 1962; GASKI, 1984). Because of this, power can be classified into two broad categories: potential and enacted power (PROVAN et al., 1980). Potential power can be defined as the capability to control others. In this case, although power exists it will not necessarily be exercised. Emerson (1962, p. 32) neatly summarises this point by saying that "power will not be, of necessity, observable in every interactive episode between A and B, yet we suggest that it exists nonetheless as a potential, to be explored, tested, and occasionally employed by the participants". Enacted power is, in turn, the actual exercise of control. When power is used in the exchange relations between actors, it is said that power is enacted, that is to say, some actors have exercised power over others (GASKI, 1984). 
Our proposition is that acquisitions have the causal power to disturb the existing balance of power among actors in networks in terms of potential and enacted power. This means that acquisitions may represent stronger network positions for some actors and weaker ones for others. In other words, an acquisition can sometimes be regarded as a platform from which a particular actor can become more powerful in relation to counterparts. Needless to say, sooner or later this actor will attempt to engage in exchange relations with these counterparts in more favourable terms (COOK, 1977).

However, acquisitions do not always make actors more or less powerful in relation to others. Rather, they entail exercising power in a different way from what has so far been exercised, which means that the potential power of an actor remains similar, but the way this power is used changes. For example, acquisitions can be used to introduce new changes into the networks by the currently more powerful actor. These changes are not caused by the increase of power of that actor. Instead, it means using the power the actor had before the acquisition in ways that have not yet been exercised.

Interestingly, this modification of the potential and/or enacted power in networks may trigger reactions from counterparts. The increase in power of some actors may, for instance, cause what some scholars, such as Forsgren and Olsson (1992), have coined 'countervailing power', that is to say, actors who perceive themselves to have become less powerful due to acquisitions may act in order to restore their original level of power. By the same token, actors can refuse to accept the new exercise of power by withdrawing from the relationship or, alternatively, searching for other sources of supply with the aim of minimising the influence of the more powerful actor (EMERSON, 1962). Therefore, changes in networks due to alterations of potential and/or enacted power are potentially susceptible to reactions of actors who are likely to be affected. Changes have to be approved and sometimes absorbed by these actors, otherwise they can be bounced back (HAKANSSON; FORD, 2002).

This discussion has led us to argue that post-acquisition changes beyond the dyad, in particular those changes that take place at the supplier and buyer nets, can be explained through the power lens. Here, two manifestations of this process are highlighted (see Figure 1). First, more powerful actors can trigger structural changes at the supplier and/or buyer net, by for instance, breaking old relationships and forming new ones (EASTON, 1992; FORSGREN; OLSSON, 1992). Secondly, more powerful actors also are in a strong position to induce non-structural changes in networks. These can be illustrated by changes in management practices introduced to suppliers and/or buyers by the dyad.

Figure 1: Power and Structural and Non-structural Changes in Networks

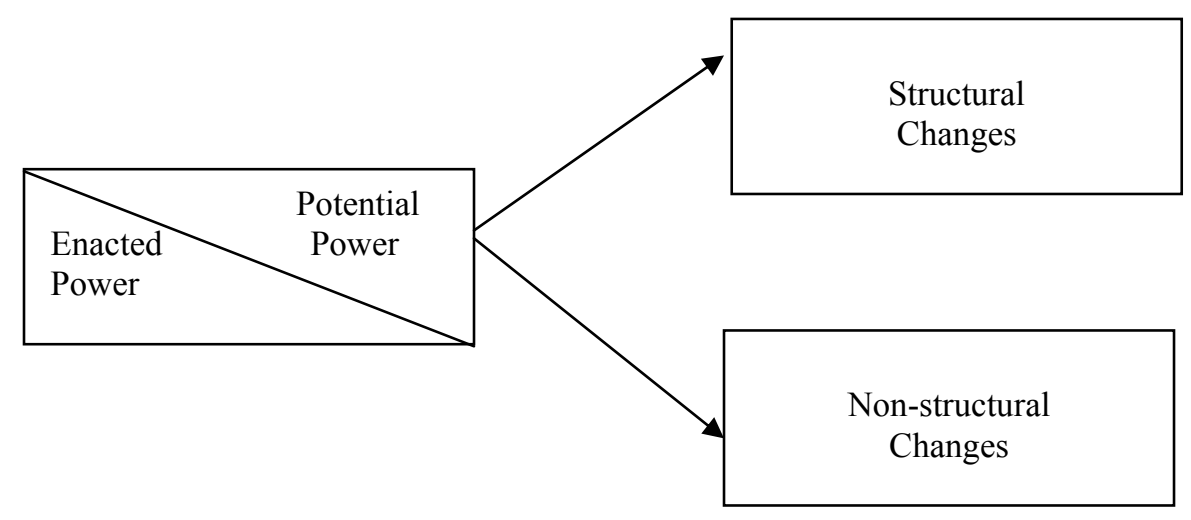

In order to illustrate post-acquisition changes beyond the dyad at the supplier and/or buyer net caused by the alteration of potential and/or enacted power, three brief cases will be presented in the next section. The cases discussed here are extracted from a large research project that aimed to examine changes in the management practices of Brazilian firms that were triggered by foreign acquisitions. Specifically, this study was carried out between 1998 and 2001 and examined 17 
Brazilian firms that were acquired by a number of foreign firms of different nationalities (DUARTE, 2001).

Our research method follows what Ragin (1987) calls the "comparative method", that is to say multiple case studies across which a comparative analysis is carried out. The comparative research method involves collecting data from a number of individual cases to subsequently compare them on the basis of the dimensions suggested by the researcher's theoretical framework.

In our case, the individual case studies were constructed from in-depth interviews with executives from both acquiring and acquired firms. In total, we carried out 15 interviews that lasted from one to three hours in length. The interviews were tape-recorded and subsequently transcribed and coded (STRAUSS, 1996). They were done in Brazil in May and July of 1999.

In terms of data analysis, we initially wrote up each case in great detail so as to maximise the explanations of it by respecting its uniqueness. Subsequently, we used different tools such as matrices in order to identify and understanding the forces and mechanisms involved in post-acquisition changes beyond the dyad. A permanent dialogue between theory and empirical evidence, carried out by alternating between induction and deduction, enabled us to write up the cases.

Whereas, in the comparative research method, the analysis of individual cases aims to identify and explain the causes that are responsible for a particular outcome, cross-case analysis seeks to maximise similarities and differences across the cases (RAGIN, 1987). In order to provide a satisfactory final explanation, the researcher is advised to carry out the comparative analysis from different angles.

In our study, we compared the cases based on the theoretical dimensions suggested earlier. This means that emphasis was given to the structural changes of the network in which the dyad, suppliers, and buyers were embedded and to non-structural changes, such as the introduction of new management practices within the supplier and buyer nets triggered by either the acquiree and/or the acquirer.

\section{CASE StUdies}

\section{Case 1 - Aquamarine}

Aquamarine, an auto parts manufacturer, was established in the 1950s with the aim of supplying the emerging Brazilian automotive industry. During its first decades it grew considerably and came to supply all carmakers implanted in Brazil. Due to financial constraints, Aquamarine had more recently decided to concentrate its efforts on a particular buyer, which represented around 65 per cent of its turnover.

In the 1990s, the Brazilian automotive industry underwent a thorough transformation. Within a much more competitive context, suppliers and buyers were, for example, required to conjointly develop new auto components. For both parties, this required technologically updated manufacturing processes and machinery as well as substantial funds for further expansion and investment.

Aquamarine did not possess either of the above resources, nor was it prepared to face the new context. At that time, a link with foreign manufacturers was regarded as imperative, although Aquamarine's owner - and directing manager - had systematically refused such a partnership. Realising that Aquamarine would no longer be able to continue operating profitably, the owner finally decided to sell the company in April 1997. The acquirer, henceforth called Turquoise, was a worldleading auto component manufacturer that had been established in Brazil for a long time.

Shortly after the acquisition, several managers, including expatriates, were appointed by Turquoise to replace Aquamarine's managerial staff. It was agreed, however, that Aquamarine's owner would 
stay on as an internal consultant for a further eighteen months. His permanence was justified on the basis that he had sound knowledge of Aquamarine and, more importantly, had himself established the relationships with carmakers, in particular Aquamarine's major buyer, henceforth called Sapphire.

In addition to a number of internal changes - organisational structure, control, HRM, and production - it was observed that important changes occurred at the network level. First, price, cost, and quality were negotiated on a more formalised basis. Relationships with suppliers thus evolved from being informal-based to more formal-based. Secondly, there was a substantial reduction of the number of suppliers, from 105 to 80 . However, the number of 'Class A' suppliers increased from nine to 32 per cent $^{(2)}$.

Initially, it was observed that quality standards were raised dramatically. This particular change was triggered when the Aquamarine quality area was incorporated into the procurement area. As the procurement manager explained, he became a sixty percent 'quality man' and a forty per cent 'procurement man'. This functional area merger indeed reflected a shift in the quality approach. Whereas Aquamarine had focused on correction, Turquoise was directed towards prevention. Instead of controlling and checking quality during and after the production process, Turquoise attempted to prevent output production problems from the beginning of its production process, which meant involving suppliers' production systems.

As Turquoise adopted a more rigorous quality control of suppliers' output, suppliers were required to change some of their management practices. For example, the Aquamarine procurement manager carried out an audit of suppliers' systems in order to pave the way for potential changes in their production systems. This involved, amongst other things, a closer involvement in suppliers' internal routines, in particular quality procedures. Also, Turquoise provided technical support.

The acquisition had effects on the buyer side as well. First, the technology provided by Turquoise to Aquamarine enabled the latter to develop new products and also to raise the quality standard of existing products. As a consequence, Aquamarine not only managed to supply other carmakers, but also increased sales to its existing buyers. Secondly, conflicts between Turquoise and Sapphire became much more frequent. Sapphire was used to requiring flexibility from its suppliers in terms of auto components development. Although Aquamarine had limited resources it had been considered a very flexible and agile firm, promptly meeting nearly all of Sapphire's requirements. However, after the take-over, Aquamarine was unable to respond as quickly as Sapphire was used to and consequently some delays occurred. In fact, as Aquamarine was compelled to follow Turquoise's procedures regarding the development of new products, it became much slower in terms of meeting Sapphire's needs.

Hence, Aquamarine faced a crossroads. On the one hand, it considered it crucial to preserve its relationships with Sapphire. This would involve developing new auto components according to the time schedule set by Sapphire, which was usually shorter than Aquamarine expected. On the other hand, Aquamarine could skip some procedures recommended by Turquoise and deliver new auto components that would not meet the quality level required. In this case, if there was a problem regarding product quality the responsibility would be Aquamarine's. As the technical director declared, 'we are forced not to follow our procedures in order not to lose this client (...) if we work as we do, we risk seeing the buyer changing the supplier (...) should something go wrong in the development of a product and quality level is not reached, the responsibility is ours'.

\section{Case 2: Topaz}

Topaz, a Brazilian cement manufacturer, was owned by three different families. It had three per cent of market share and its plant was located in a poor countryside area that allowed Topaz to benefit from significant local and national tax exemptions. This was said to have counterbalanced the mismanagement of the firm for years. 
In the early 90s Topaz was faced with a critical situation. At that time it was controlled by the second and third generations of the three original families. This resulted in a number of conflicts including the problem of the succession of the firm. In addition, the cement industry underwent a crisis following the de-regulation of the industry ${ }^{(3)}$.

In December 1996 Topaz was taken over by Amethyst, a French firm and world leader in the cement industry. Two important changes at the network level can be identified. First, as Topaz began placing much larger orders, its bargaining power with suppliers increased considerably. For example, packaging is an important input for the cement industry as it impacts significantly on final prices. Cheaper packaging means, amongst other things, lower costs. When Topaz was acquired, it was used to placing orders that amounted to a million bags. Shortly afterwards, its orders rose to ten million bags.

Secondly, following Amethyst's guidance there was a shift in the distribution system hitherto used by Topaz: from wholesaling to retailing. This included, amongst other things, weakening wholesalers by restricting their credit and establishing product quotas. As a result, a number of wholesalers, especially those heavily dependent on Topaz, went bankrupt, while others, in order to survive, were compelled to shift to other cement producers or, alternatively, to substantially increase sales of cement-related products. Three years after the acquisition, there were only a few remaining wholesalers, which were the largest firms. In the long term, however, Amethyst expected to terminate Topaz's relationships with them in order to distribute cement only through retailers.

\section{Case 3: Citrine}

Citrine was a family-owned, milk-based sweet firm founded in 1968 and based in a very small city. Because of this, it played an important economic role in the local area. In addition to being a major employer, Citrine was supplied by around 2,000 small farmers, who were in some cases highly dependent on it. In October 1995, Citrine was acquired by Tourmaline, an American food firm that manufactured a variety of products such as biscuits, jelly, and dairy products. It had been operating in Brazil since the 1930s and had recently acquired a number of firms in Brazil.

Following the acquisition, the supply system went through a radical transformation. Broadly speaking until the acquisition, the milk was collected daily in the farms and subsequently brought in to the plant for further processing. As soon as the milk was delivered, its quality was checked. Following the acquisition, the milk was no longer placed in several churns but in a huge lorry tank. This meant that quality checking had to be carried out by the drivers at the moment of collection so as to avoid mixing poor and good quality milk in the same tank. More importantly, as the milk was no longer collected daily, it had to be refrigerated as soon as it was milked. This last requirement entailed a major change for suppliers as they were compelled to purchase refrigerators. However, some farmers had scarce financial resources and could not afford it. On some farms there was not even electricity.

Realising these difficulties, the acquirer attempted to work closely with its suppliers. Every single farmer was visited in order to receive information about how the supply system would work from that time onwards. In addition, Citrine helped the farmers by lending money for the purchase of refrigerators and by explaining how the milk should be milked, stored, and delivered, amongst other things.

However, an adverse reaction against the new supply system emerged. Some farmers refused to buy refrigerators, seeing it as a pointless requirement of a multinational. Others opted to supply only firms that collected milk using the system they were used to. As a result, the number of Citrine's suppliers gradually decreased from 2,000 to 500. Nevertheless, the total amount of milk supplied increased.

Interestingly, some of the farmers who refused to participate in the new supply system were later taken over by competitors. In addition, some of Citrine's competitors gradually started adopting a similar supply system, which in turn drove their suppliers to alter their milk supply practices. The milk suppliers who had stuck to the previous system began to face difficulties in finding potential buyers. 


\section{UNDERSTANDING THE CASE STUDIES}

The cases of Aquamarine, Topaz, and Citrine illustrate post-acquisition changes beyond the dyad, i.e. changes following acquisitions that were not confined to the acquirer and acquiree (HALINEN et. al., 1999). This means that direct and indirect connected relationships to the dyad were affected by acquisition operations (HAVILA; SALMI, 2002). More importantly, our research illustrates two other issues. First, changes in terms of type and strength can be distinguished at the net level. Type of change has to do with the content of change whereas strength of change is related to the impact of the change on the network such as revolutionary and evolutionary changes (HAVILA; SALMI, 2000). Secondly, potential and/or enacted power can be regarded as an independent variable in postacquisition changes beyond the dyad.

In relation to the former, our data suggest that changes in the supplier net are not necessarily similar to changes in the buyer net. It appears that changes in the supplier net are more related to technical development whereas changes in the buyer net are linked to marketing policies and distribution. The case of Aquamarine nicely illustrates this point to the extent that there were a number of technical developments in terms of new production processes at the supplier net and changes related to delivery practices in the buyer net.

In our opinion, this finding is interesting because it may represent a more fine-grained analysis of post-acquisition changes beyond the dyad. More specifically, in their framework of changes in networks Halinen et al. (1999, p. 784) have proposed that "changes in the connected relationships need not be of the same kind as the changes in the focal dyad'. Although our data suggest that this proposition holds true (e.g. the case of Aquamarine), it also points to a different, yet complementary issue, i.e. changes may also vary in connected relationships. As changes in networks are not similar, connected relationships embedded either in buyer or supplier nets should not theoretically be regarded as homogeneous. Rather, they should be differentiated according to types of changes.

Interestingly, changes also appear to vary in connected relationships in terms of strength, that is to say, changes classified as revolutionary and evolutionary (HAVILA; SALMI, 2000). This can be exemplified by the case of Topaz. Following the acquisition, the structure of the supplier net remained quite similar, i.e. new relationships were not created, nor did old relationships break off. However, the buyer net was nearly re-structured in its entirety to the degree that the acquiree decided to operate with a new distribution system: wholesaling instead of retailing.

This particular finding means the proposition developed by Havila and Salmi (2000) concerning revolutionary changes following acquisitions needs to be refined. The authors associate acquisitions with revolutionary changes to the degree that development and termination of relationships are involved. We build upon their work by arguing that revolutionary and evolutionary changes can coexist in the same network. This means that parts of the network may be radically transformed after an acquisition, whereas other parts may remain more or less unaffected. This finding, in turn, entails conceptualising networks as consisting of distinct nets where revolutionary and evolutionary changes are likely to occur simultaneously.

More generally, the conclusion that types and strength of changes occur heterogeneously in networks can be interpreted as another piece of evidence of the paradoxical nature of network structures (HAKANSSON; FORD, 2002), i.e. phenomena apparently viewed as contradictory can coexist in networks (EASTON; LUNDGREN, 1992).

The second issue of this article points to relational power as an independent variable in postacquisition changes beyond the dyad. Accordingly, our data suggest that structural and non-structural changes were dependent on the potential and/or enacted power held by the dyad, its suppliers, and 
buyers. Or, to put it differently, structural and non-structural changes can be explained by the disturbance of the existing power balance and/or the new exercise of power. These changes resulted from the actors' attempts to keep, increase, or alternatively, not lose the potential power they had before the acquisition as well as from the use of an actors' existing power in a different way from what it had been exercising up to that moment.

The case of Citrine nicely illustrates how power - in this case enacted power - triggered structural changes in networks. Citrine was already more powerful than its suppliers when it was acquired by a multinational. The acquisition operations induced Citrine to use its power in different ways, such as presenting new requirements for suppliers in terms of the collection and delivery of milk. Because some suppliers were not prepared and, more importantly, not willing to meet the new requirements, a revolutionary change ensued, i.e. a number of direct and indirect relationships between Citrine and actors embedded in the supply net were broken. This means that those suppliers that did not change their practices were excluded from Citrine's supply system.

The same line of reasoning applies to non-structural changes in networks which, in this article, are illustrated by changes in management practices of actors connected to the dyad. Interestingly, nonstructural changes are the most pervasive changes in our data, which means that all three cases portray either the dyad or the acquiree attempting and effectively succeeding in introducing new management practices to either the buyers or the suppliers. For example, the case of Aquamarine clearly points to the dyad imposing new requirements on suppliers which, in turn, provoked a series of internal changes in these actors in terms of new production practices. Our data suggest that this process can be explained by differences of power between the dyad and the suppliers. Had these actors (the suppliers) had more power, the changes of management practices would probably not have been carried out. Alternatively, these actors might not have complied with the requirements presented by the dyad without resistance.

Although most of our data show changes being forcefully introduced to actors connected to the dyad due to power differences between them, it is important to bear in mind that changes can be bounced back. Once again, the case of Aquamarine is illustrative. On the one hand, Aquamarine found no major difficulties in introducing changes at the supplier net. On the other hand, one of its buyers, Sapphire, did not accept changes that Aquamarine aimed to impose on the buyer net where it was embedded. This means that the power of Aquamarine in introducing structural and non-structural changes at the buyer level was subject to the countervailing power of another actor (GASKI, 1984; FORSGREN; OLSSON, 1992).

Summing up, it has beer observed that the existing balance of potential and enacted power of actors embedded in distinct nets of the network was considerably affected when a particular firm in the network was acquired by another firm. Usually, this disturbance triggered structural and non-structural changes in the network, which did not mean that changes were unilaterally provoked. Any potential change was subject to the ability of connected actors to inhibit the dyad's power (GASKI, 1984). Due to this interdependence, we suggest that it is hard to plan post-acquisition changes beyond the dyad because they are contingent upon the actions and reactions of actors who are involved in the acquisition process such as the dyad, suppliers, and buyers.

We also propose that potential and/or enacted power should be regarded as an independent variable for understanding post-acquisition changes beyond the dyad. Analysing who the most powerful actors were before the acquisition, how this power was exercised and how the acquisition has changed the balance of power amongst actors should go hand in hand with the analysis of structural and nonstructural changes that eventually take place at the net level. 


\section{FINAL REMARKS}

When an acquisition takes place, a plethora of events are likely to occur. First, the acquirer usually introduces changes, in particular new management practices, to the acquiree. This has been the traditional focus of the literature on acquisition, especially the management and integration of acquisitions strand (e.g. CHILD et al., 2001). Secondly, changes taking place within the dyad, i.e. acquirer and acquiree, may affect some actors connected directly and/or indirectly to either part. Changes in connected relationships are, in turn, sources of changes that occur within and between these actors (HAKANSSON; FORD, 2002).

The three cases presented in this article nicely illustrate this interdependence between the dyad and its network context. As a result, post-acquisition changes are viewed as being circular rather than unidirectional (HALINEN et al., 1999). Flowing in various directions through different network nodes, they affect actors located in different parts of the network (EASTON; LUNDGREN, 1992). In other words, post-acquisition changes go beyond the dyad.

Here, the changes revolved around the sources and/or exercise of power held by actors embedded in distinct nets. This means that the acquisition entailed different power relations in terms of potential and/or enacted power at the supplier and/or buyer nets. In this sense, our proposition is that an analysis of post-acquisition changes beyond the dyad should not be detached from an analysis of power at the net level. Through the power lens, these changes can be identified, analysed and, more importantly, comprehended.

Based on our research, this article describes implications and directions for further research. First, as post-acquisition changes appear to flow in various directions, it could be interesting to focus on flows that do not conform to the traditional pattern described in the literature on acquisition, that is to say, from the acquirer to the acquiree. For instance, the analyst may choose to understand changes reflected by the acquiree to the acquirer and its respective connected relationships. To the best of our knowledge, this issue has not yet been systematically examined in the literature on acquisition.

Secondly, as discussed here, scholars should consider that changes in management practices at the level of the dyad might be linked to changes that take place at the net level such as at the level of supplier and/or buyer nets. On the one hand, the dyad may request or impose new management practices on connected relationships, subject to the power relations of the network. On the other hand, this attempt can be bounced back, that is to say, connected actors may refuse to accept these management practices and, consequently, drive the dyad to find a balance between what it wants in terms of new management practices and what it can practically achieve.

Therefore, scholars who view both phenomena - changes of management practices at the level of the dyad and beyond the dyad - as if they were two distinct things run the risk of missing the sequence of changes that may follow acquisitions, of attributing causes to the wrong driving forces, amongst other things. Future research into new management practices induced by acquisition operations should consider that this type of change may occur concurrently within the acquiree, between the acquireracquiree and beyond the dyad.

Thirdly, power should be explicitly considered as an independent variable in frameworks for analysing post-acquisition changes beyond the dyad. In doing so, future research should shed light on the relationships between potential and enacted power in acquisition operations. What are the mechanisms that activate potential power following operations? What are the mechanisms that drive the dyad to exercise power in different ways from the past? Does potential power trigger structural and non-structural changes that are distinct from those triggered by enacted power? If so, why? These questions can be used as a starting point for future empirical investigation. 


\section{NOTES}

\footnotetext{
${ }^{1}$ An earlier version of this article was presented at the XXVII ENANPAD and awarded as the best article of the international management track. We appreciate the comments of the conference participants and are also grateful to Maria Amália de Freitas, Liliane Guimarães and Luis Araujo for comments on the earlier drafts. Special thanks to Virpi Havila for her insightful suggestions and for her encouragement. Research support from Capes and FIP/PUC-Minas is gratefully acknowledged. The usual disclaimers apply.

${ }^{2}$ A 'Class A' supplier holds an ISSO 9000 certificate.

${ }^{3}$ One of the consequences of the de-regulation of the Brazilian cement industry was related to prices. Cement prices were initially controlled by the government. With de-regulation, prices started to fluctuate more or less freely and consequently firms ended up involved in much fiercer competition.
}

\section{REFERENCES}

ANDERSON, H.; HAVILA, V.; SALMI, A. Can You Buy a Business Relationship? On the Importance of Customer and Supplier. Relationships in Acquisitions. Industrial Marketing Management, v. 30, p. 575-586, 2001.

BENSON, T. Determinants of Power of Boundary Units in an Interorganizational Barganing Relation, Administrative Science Quarterly, v. 20, June, p. 229-249, 1975.

BIRKINSHAW, J.; BRESMAN, H.; HAKANSON, L. Managing the Post-acquisition Integration Process: How the Human Integration and Task Integration Processes Interact to Foster Value Creation, Journal of Management Studies, v. 3, n. 3, p. 395-425, 2000.

CHILD, J.; FAULKNER, D. O.; PITKETHLY. Changes in management practice and the postacquisition performance achieved by foreign investors in the UK, British Journal of Management, $\mathrm{v}$. 10, p. 85-98, 1999.

CHILD, J.; FAULKNER, D. O.; PITKETHLY R. The Management of International Acquisitions, Oxford: Oxford University Press, 2001.

COOK, K. Exchange and Power in Networks of Interorganizational Relations, The Sociological Quarterly, v. 18, Winter, p. 62-82, 1977

DATTA, D. K.; GRANT, J. H. Relationships Between Type of Acquisition, the Autonomy Given to the Acquired Firm, and Acquisition Success: an Empirical Analysis, Journal of Management, v. 16, n. 1 , p. 29-44, 1990.

DAVID, K.; SINGH, H. Sources of Acquisition Cultural Risk. In: VON KROGH, G.; SINATRA, A.; SINGH, H. (Eds.). The Management of Corporate Acquisitions: International Perspectives, London: The Macmillan Press Ltd, p. 251-292, 1994.

DAVIS, R. E. Compatibility in Corporate Marriages, Harvard Business Review, July-August, p. 8693, 1968.

DUARTE, R. Cross-border Acquisitions and Changes in Domestic Management Practices - the Case of Brazil. Unpublished Ph.D thesis, University of Cambridge, 2001.

EASTON, G. Industrial Networks: a Review. In: AXELSSON, B.; EASTON, G. (Eds.), Industrial Networks: a New View of Reality. London: Routledge, p. 3-27, 1992. 
EASTON, G.; LUNDGREN, A. Changes in Industrial Networks as Flow through Nodes. In: AXELSSON, B.; EASTON, G. (Eds.). Industrial Networks: a New View of Reality. London: Routledge, p. 89-104, 1992.

EMERSON, R. Power-Dependence Relations. American Sociological Review, v. 27, n“ 1, p. 31-41, 1962.

FARIA, A; WENSLEY, R. In seach for 'Interfirm Management' in Supply Chains: Recognizing Contradictions of Language and Power by Listening. Journal of Business Research, v. 55, p. 603$610,2002$.

FORSGREN, M.; OLSSON, U. Power Balancing in an International Business Network. In: FORSGREN, M.; JOHANSON, JAN. (Eds). Managing Networks in International Business, Philadelphia, Penn: Gordon and Breach, 1992.

GALASKIEWICZ, J. Interorganizational Relations. Annual Review of Sociology, v. 11, p. 281-304, 1995.

GASKI. J. The Theory of Power and Conflict in Channels of Distribution. Journal of Marketing, Summer, p. 9-29, 1984.

HAKANSSON, H.; SNEHOTA, I. Developing Relationships in Business Networks, London: Routledge, 1995.

HAKANSSON, H.; FORD, D. How Should Companies Interact in Business Networks? Journal of Business Research, v. 55, p. 133-139, 2002.

HALINEN, A.; SALMI, A.; HAVILA, V. From Dyadic Change to Changing Business Networks: an Analytical Framework. Journal of Management Studies, v. 36, n. 6, p. 779-794, 1995.

HASPELASGH, P. C.; JEMISON, D. B. Managing Acquisitions: Creating Value through Corporate Renewal. New York: The Free Press, 1991.

HAVILA, V.; SALMI. A.Internationalisation through Acquisitions: Spread of Change in Business Networks. Paper presented at the Marcus Wallenberg Symposium on Critical Perspectives on Internationalisation, Uppsala: Sweden, p. 1-23, 2000.

HAVILA, V.; SALMI, A. Network Perspective on International Mergers and Acquisitions: What More do We See? In: HAVILA, V.; FORSGREN, M.; HAKANSSON, H. (Eds.) Critical Perspectives on Internationalisation. Oxford: Pergamon, p. 457-472, 2002.

HITT, M.; HARRISON, J.; IRELAND, R. D.; BEST, A. Attributes of Successful and Unsuccessful Acquisitions of US Firms. British Journal of Management, v. 9, p. 91-114, 1998.

HUNT, J. W. Changing Pattern of Acquisition Behaviour in Takeovers and the Consequences for Acquisition Processes. Strategic Management Journal, v. 11, p. 69-77, 1990.

JACOBS, D. Dependency and Vulnerability: an Exchange Approach to the Control of Organizations, Administrative Science Quarterly, v. 45, p. 45-59, 1974.

KANTER, R. M.; CORN, R. I. Do Cultural Differences Make a Business Difference? Contextual Factors Affecting Cross-cultural Relationship Success. Journal of Management Development, v. 13, n. 2, p. 523, 1994. 
KITCHING, J. Winning and Losing with European Acquisitions. Harvard Business Review, MarchApril, p. 124-36, 1974.

KRUGER, W.; MUlLER-STEWENS, G. Matching Acquisition Policy and Integration Style. In: VON KROGH, G.; SINATRA, A.; SINGH, H. (Eds.), The Management of Corporate Acquisitions: International Perspectives, London: The Macmillan Press Ltd, p. 50-87, 1994.

LINDGREN, U.; SPANGBERG, K. Management of the post-acquisition process in diversified MNCs. In: Otterberck, L. (Ed.), The Management of Headquarters-subsidiary Relationships in Multinational Corporations, Aldershot: Gower, p. 32-53, 1981.

LORANGE, P. Preparing for Value Creation in a Complex Merger among Firms in Similar Business: Synergy Generation and Distribution Issues. In: VON KROGH, G.; SINATRA, A.; SINGH, H. (Eds.). The Management of Corporate Acquisitions: International Perspectives, London: The Macmillan Press Ltd, p. 88-104, 1994.

LUBATKIN, M.; CALORI, R.; VERY, P.; VEIGA, J. F. Managing Mergers Across Borders: a Twonation Exploration of a Nationally Bound Administrative Heritage. Organization Science, v. 9, n. 6, p. 670-84, 1998.

NAHAVANDI, A.; MALEKZADEH, A. R. Successful Mergers through Acculturation. In: VON KROGH, G.; SINATRA, A.; SINGH, H. (Eds.). The Management of Corporate Acquisitions: International Perspectives, London: The Macmillan Press Ltd, p. 293-306, 1994.

PABLO, A.L. Determinantes of Acquisition Integration Level: a Decision-making Perspective. Academy of Management Journal, v. 37, n. 4, p. 803-836, 1994.

PROVAN, K.; BEYER, J.; KRUYTBOSH, C. Environmental Linkages and Power in Relations between Organizations. Administrative Science Quarterly, v. 25, June, 1980, p. 200-225, 1980.

RAGIN, C. C. The Comparative Method: Moving beyond Qualitative and Quantitative Strategies, Berkely: University of California Press, 1987.

SCHWEIGER, D. M.; IVANCEVICH, J. M.; POWER F. R. Executive Actions for Managing Human Resources Before and After Acquisition. Academy of Management Executive, v. 1, n. 2, p.127-138, 1987.

SINATRA, A.; DUBINI, P. Predicting Success After the Acquisition: the Creation of a Corporate Profile. In: VON KROGH.; SINATRA, A.; SINGH, H. (Eds.), The Management of Corporate Acquisitions: International Perspectives. London: The Macmillan Press Ltd, p. 480-512, 1994.

SMITH, P.; LAAGE-HELLMAN, J. Small Group Analysis in Industrial Networks. In: AXELSSON, B.; EASTON, G. (Eds.), Industrial Networks: a New View of Reality, London: Routledge, p. 13-27, 1992.

STRAUSS, A. L. Qualitative Analysis for Social Scientists, Cambridge: Cambridge University Press, 1996.

UNITED NATIONS CONFERENCE ON TRADE AND DEVELOPMENT (UNCTAD). World Investment Report 2000. New York: United Nations, 2000.

VON KROGH, G. Implementing Strategy in a Newly Acquired Firm. In: VON KROGH, G.; SINATRA, A.; SINGH, H. (Eds.). The Management of Corporate Acquisitions: International Perspectives, London: The Macmillan Press Ltd, p. 307-337, 1994. 
WILKINSON, I.; YOUNG, L. On Cooperating: Firms, Relations and Networks. Journal of Business Research, v. 55, p. 123-132, 2002.

ZEITZ, G. Interorganizational Dialectics. Administrative Science Quarterly, v. 25, March, p. 72-88, 1980. 